\title{
Penggunaan Metode Suku Kata (Syllabic Method) Untuk Meningkatkan Kemampuan Membaca Permulaan Pada Siswa Kelas 1 SDN 009 Tarakan
}

\author{
Suyadi, Riska Putri Sari \\ Universitas Borneo Tarakan \\ suyadisastranegara@gmail.com
}

\section{Article History}

received 24/3/2021

\begin{abstract}
The study aims to determine the use of syllabic method to improve initial reading in grade I-B students at SDN 009 Tarakan. This research uses classroom action research which is carried out for 2 cycles with designs or stages starting from planning, implementing, observing and reflecting. The research subjects were 28 students consisting of 16 male students and 12 female students. The data were collected using the oral test on reading. The results of this study indicate that the application of the syllable method increasing the ability of initial reading of each cycle. In the first cycle, the initial reading ability test result was $65 \%$. In the second cycle the increase in the increase, the result of the initial reading ability test was $73 \%$. The syllabic method can improve the initial reading ability of the first grade students of SDN 009 Tarakan.
\end{abstract}

Keywords: Student, syllabic method, initial reading ability.

\begin{abstract}
Abstrak
Tujuan penelitian ini yaitu untuk mengetahui penerapan guru dalam penggunaan metode suku kata (syallabic methoad) pada siswa kelas I-B di SDN 009 Tarakan. Jenis Penelitian ini menggunakan penelitian tindakan kelas yang dilaksanakan sebanyak 2 siklus dengan desain atau tahapan mulai dari perencanaan, pelaksanaan, pengamatan dan refleksi. Subjek penelitian siswa sebanyak 28 yang terdiri dari 16 siswa laki-laki dan 12 siswa perempuan. Pengumpulan data menggunakan tes lisan membaca permulaan. Hasil penelitian ini menunjukkan bahwa penerapan metode suku kata (syllabic method) dapat mempengaruhi kemampuan membaca permulaan ditandai dengan terjadi peningkatan kemampuan membaca permulaan pada setiap siklus. Pada siklus I hasil tes kemampuan membaca permulaan sebesar $65 \%$. Pada siklus II mengalami peningkatan, hasil tes kemampuan membaca permulaan sebesar 73\%. Metode suku kata (Syllabic Methoad) dapat meningkatkan kemampuan membaca permulaan pada siswa kelas I SDN 009 Tarakan.

Kata kunci: Siswa, metode suku kata, kemampuan membaca permulaan.
\end{abstract}




\section{PENDAHULUAN}

Pendidikan yang berkualitas dan sesuai dengan tujuan pendidikan akan menghasilkan lulusan yang berkualitas pula. Oleh karena itu pendidikan di sekolah dasar diharapkan menghasilkan pembelajaran yang baik siswa. Pembelajaran di kelas maupun diluar kelas sejatinya memberi pengalaman-pengalaman belajar yang luar biasa bagi peserta didik, salah satunya mata pelajaran Bahasa Indonesia. Pembelajaran Bahasa Indonesia terdapat beberapa aspek. Keterampilan berbahasa mencakup empat segi yaitu keterampilan menyimak, keterampilan berbicara, keterampilan membaca dan keterampilan menulis (Efendi \& History, 2017).

Pada proses pembelajaran di kelas maupun di luar kelas tentu tidak terlepas dari kemampuan berbahasa salah satunya membaca. Membaca merupakan salah satu jenis kemampuan berbahasa yang bersifat reseptif (Setiyoso et al., 2020). Membaca sebagai kegiatan yang penting dalam kehidupan sehari-hari, karena tidak hanya untuk memperoleh informasi, tetapi juga sebagai alat untuk memperluas pengetahuan seseorang (Rusminiati et al., 2018). Secara lebih spesifik(Ayu \& Sudarsini, 2016) menyampaikan bahwa membaca merupakan salah satu bagian perkembangan bahasa yang membutuhkan pemahaman simbol secara verbal. Kemudian ditambahkan oleh Herdianingsih et al., (2019), membaca merupakan suatu hal rumit dengan melibatkan banyak hal, tidak hanya melafalkan tulisan, tapi juga melibatkan aktivitas visual, berfikir, psikolinguistik, dan metakognitif. Jadi membaca merupakan salah satu kemampuan yang harus dimiliki peserta didik yang melibatkan berbagai aspek kemampuan siswa.

Kompetensi aspek membaca di kelas rendah SD/MI adalah siswa mampu membaca dan memahami teks pendek dengan cara membaca lancar (bersuara) dan membaca nyaring beberapa kalimat se- derhana. Kompetensi ini diturunkan ke dalam empat buah kompetensi dasar, yakni: 1) membiasakan sikap membaca yang benar, 2) membaca nyaring, 3) membaca bersuara (lancar), 4) membacakan penggalan cerita (Halimah, 2014). Hal ini menunjukkan bahwa salah satu kompetensi Bahasa Indonesia juga diarahkan menumbuhkan budaya membaca. Siswa yang lebih banyak membaca, maka semakin meningkat pula kemampuan siswa dalam membaca (Nurhyati et al., 2016).

Pembelajaran membaca permulaan merupakan tingkatan proses pembelajaran membaca untuk menguasai sistem tulisan sebagai representasi visual bahasa. Penekanan pembelajaran membaca pada kelas awal SD adalah pada penguasaan sistem tulisan atau teknik membaca (Muhyidin, 2017). Pembelajaran membaca di sekolah dasar biasanya dimulai dari tahapan membaca permulaan. Pada umumnya, siswa kelas awal sudah memiliki kemampuan membaca, sehingga ia tidak akan mengalami kesulitan dalam mempelajari bidang studi pada kelas lanjutannya (Hidayah \& Nawawi, 2017).

Membaca permulaan merupakan tahapan proses belajar membaca bagi siswa sekolah dasar kelas awal (Kumullah et al., 2019). Kemampuan membaca permulaan merupakan kegiatan yang memadukan antara pengenalan huruf dan kata lalu menghubungkannya dengan bunyi. Sejalan dengan itu membaca permulaan menurut (Basuki, 2019) merupakan proses pemahaman hubungan antara huruf dengan bunyi bahasa dengan cara mengubah simbol-simbol tertulis yang berupa deretan huruf atau kata menjadi system bunyi. Kemampuan membaca permulaan merupakan kegiatan yang melibatkan aktifitas visual dalam memahami simbol atau tulisan yang diucapkan oleh siswa dan menitikberatkan pada kemampuan awal dalam membedakan struktur bunyi yang terdapat pada tiap huruf maupun gabungan huruf dalam kata yang dilafalkan dengan jelas, lancar dan tepat (Furoidah \& Rohinah, 2019).

Berdasarkan beberapa penjelasan di atas dapat disimpulkan bahwa kemampuan membaca permulaan merupakan suatu tahapan dalam proses belajar membaca khususnya kelas rendah. Oleh karena itu, siswa diharapkan mampu menguasai kemampuan tersebut agar dapat mengikuti pembelajaran di jenjang berikutnya dengan 
baik tanpa hambatan mengenai kemampuan membaca. Namun pada kenyataannya, masih terdapat siswa yang belum menguasai kemampuan membaca di kelas rendah.

Berdasarkan data yang diperoleh di SDN 009 Tarakan khususnya di kelas I-B pada semester genap tahun ajaran 2019/2020 telah diperoleh data dengan hasil: kemampuan siswa mengenal huruf $85 \%$, kemampuan siswa membaca suku kata 57,14\%, dan kemampuan siswa dalam membaca kata $40,71 \%$, sehingga rata-rata keseluruhan aspek membaca permulaan $60,95 \%$ dengan kategori cukup. Permasalahan tersebut disebabkan oleh: 1) kurangnya variasi guru dalam penerapan metode pembelajaran pada saat pembelajaran, 2) terdapat siswa yang hanya menghafal bunyi huruf namun tidak mengetahui bentuk dari huruf yang diucapkannya, 3) terdapat siswa yang tidak mampu membaca dengan tepat, dan 4) siswa hanya membaca jika mendapatkan paksaan dari guru.

Dari permasalahan di atas, peneliti menawarkan solusi dengan menerapkan metodesuku kata (syllabic method) dalam meningkatkan kemampuan membaca permulaan. Permainan suku kata merupakan salah satu permainan bahasa yang digunakan untuk mengembangkan kemampuan membaca permulaan (Yuliana, 2009). Metode menguraikan suku kata dapat membantu siswa memahami struktur kata yang dibaca (Alfiah \& Umar, 2018). Metode suku kata adalah cara pengenalan huruf kepada siswa dengan merangkaikan suku kata menjadi huruf dan akhirnya menjadi kata untuk menunjukkan bahwa membaca merupakan kesatuan kegiatan seperti mengenali huruf dan kata-kata, menghubungkannya dengan bunyi dan maknanya, serta menarik kesimpulan mengenai maksud jawaban (Havisa et al., 2021).

Adapun langkah-langkah dalam penerapan metode suku kata (syllabic method), sebagai berilut: (a) Guru merangkaikan atau menggabungkan huruf konsonan dengan huruf vocal berdasarkan teks yang ada di buku dan dibaca bersama siswa; (b) Guru menuliskan kata-kata yang sudah dikupas menjadi suku kata lalu membaca bersama siswa; (c) Guru merangkaikan/ menuliskan suku kata menjadi kata yang sudah di rangkai lalu dibaca bersama siswa; (d) Kemudian guru merangkai/ menuliskan menjadi kalimat lalu di baca bersama siswa. Alasan peneliti ingin menerapkan metode suku kata adalah dengan adanya metode suku kata siswa dapat belajar membaca dengan memenggal kata tersebut menjadi suku kata.

Membaca dengan menggunakan metode suku kata membuat anak mudah memahami dan mencermati materi yang disajikan guru. Menurut (Mustikawati, 2015) metode suku kata adalah suatu metode yang memulai pengajaran membaca permulaan dengan menyajikan kata-kata yang sudah di rangkai menjadi suku kata, kemudian sukusuku kata itu di rangkai, yang terakhir merangkai kata menjadi kalimat.Selain itu, latihan membaca dengan suku kata (syllablic method) dapat memungkinkan siswa yang memiliki kemampuan membaca rendah untuk mengenali kata-kata dengan lebih akurat dan dengan sedikit upaya (Müller et al., 2020). (Mustikawati, 2015) yang menjelaskan bahwa, dengan penerapan metode suku kata dapat meningkatkan keterampilan belajar membaca permulaan siswa di kelas I SD. Program pelatihan yang menggunakan suku kata sebagai sebuah unit untuk meningkatkan pengkodean fonologis dan membaca kata (Ecalle et al., 2013). Berdasarkan penjabaran di atas peneliti tertarik melakukan penelitian dengan judul "Meningkatkan Kemampuan Membaca Permulaan Melalui Metode Suku Kata (Syllabic Method) Pada Siswa Kelas I-B di SDN 009 Tarakan".

\section{METODE}

Penelitian yang dilakukan dalam penelitian ini adalah Classroom Action Research atau Penelitian Tindakan Kelas (PTK). Penelitian tindakan kelas adalah penelitian yang mana memaparkan terjadinya sebab-akibat dari perlakuan, dan memaparkan seluruh proses sejak awal pemberian perlakuan sampai dampak dari perlakuan tersebut. Penelitian ini dilaksanakan dalam dua siklus. Masing-masing siklus terdiri dari 4 tahapan. 
Empat tahap utama yang ada pada setiap siklus terdiri dari: 1) perencanaan (planning), 2) pelaksanaan (acting), 3) pengamatan (observing), dan4) refleksi (reflecting).

Penelitian tindakan kelas ini dilakukan di SDN 009 Tarakan terletak di Jl. Kamboja RT. 31, Kelurahan Karang Anyar, Kecamatan Tarakan Barat, Kota Tarakan, Provinsi Kalimantan Utara. Subjek penelitian ini adalah siswa kelas I-B SDN 009 Tarakan yang berjumlah 28 orang. Penelitian ini dilaksanakan pada tanggal 24 Februari 2020 s/d 07 Maret 2020 (sebelum pandemi covid-19), pada semester genap tahun pembelajaran 2019/2020 pada Tema VI "Lingkungan Sehat, Bersih dan Asri" dan Subtema 3 "Lingkungan Sekolahku". Validitasi dalam penelitian ini menggunakan validasi rubrik penilaian kemampuan membaca permulaan. Teknik pengumpulan data yang digunakan dalam penelitian ini yaitu teknik tes dan non-tes. Tes yang digunakan adalah tes lisan yang bertujuan untuk mengukur kemampuan membaca permulaan dan teknik non-tes berupa observasi dan studi dokumen. Instrumen penelitian merupakan alat yang digunakan peneliti untuk mengumpulkan data atau informasi dari hasil pelaksanaan tindakan. Instrumen yang digunakan dalam penelitian ini yaitu instrumen tes (Peniilaian Kemampuan Membaca Permulaan).

Teknik analisis data yang digunakan adalah Penilaian Kemampuan Membaca Permulaan. Penilaian yang di gunakandalampenelitianiniyaitupenilaian tes yang bertujuan untuk mengukur kemampuan membaca permulaan siswa. Kemampuan membaca permulaan siswa dapat dihitung dengan menggunakan persamaan berikut.

$$
\text { Nilai }=\frac{\text { skor yang diperoleh }}{\text { skor maksimal }} \times 100
$$

Setelah memperoleh hasil penilaian kemampuan membaca permulaan, nilai tersebut kemudian diklasifikasikan berdasarkan rentang nilai sebagai berikut:

Tabel 1. Rentang Kemampuan Membaca Permulaan Siswa

\begin{tabular}{lll}
\hline Presentase Membaca (\%) & Huruf & Kategori \\
& & \\
\hline $80-100$ & A & Sangat Baik \\
$66-79$ & B & Baik \\
$56-65$ & C & Cukup \\
$40-55$ & D & Kurang \\
\hline
\end{tabular}

\section{HASIL DAN PEMBAHASAN}

Penelitian tindakan kelas ini bertujuan untuk meningkatkan kemampuan membaca permulaan melalui penerapan metode suku kata (syllabic method) pada Tema 6 "Lingkungan Bersih, Sehat dan Asri". Penelitian ini telah dilaksankaan pada siswa kelas I-B SDN 009 Tarakan yang berjumlah 28 siswa, yang terdiri dari 16 siswa laki-laki dan 12 siswa perempuan. Penelitian ini dilaksanakan pada semester genap tahun ajaran 2019/2020 yang dimulai pada tanggal 24 Februari 2020 s/d 07 Maret 2020.

Setiap siklus pada penelitian ini terdiri dari enam kali pertemuan dengan alokasi waktu $5 \times 35$ menit setiap pertemuan. Peningkatan pada siklus I ke siklus II adalah sebagai berikut:

\section{Hasil Tes Kemampuan Membaca Permulaan Siswa Siklus I}


Pada siklus I pengambilan data hasil tes kemampuan membaca permulaan kelas I-B SDN 009 Tarakan dengan menerapkan metode suku kata (syillabic method) dilakukan setiap akhir siklus yaitu dipertemuan keenam.

Nilai kemamapuan membaca siklus I berdasarkan aspek kemampuan membaca permulaan dideskripsikan pada tabel berikut ini:

Tabel 2. Nilai Kemampuan Membaca Siklus I Berdasarkan Aspek

\begin{tabular}{rrc}
\hline No. & Aspek & Persentase \\
\hline 1. & Mengenal Huruf & 90 \\
2. & Membaca Suku Kata & 61 \\
3. & Membaca Kata & 44 \\
\hline & Jumlah & 198 \\
\hline & 65 \\
\hline & Rata-rata & Cukup \\
\hline
\end{tabular}

Berdasarkan tabel diatas menunjukkan bahwa nilai rata-rata pada aspek mengenal huruf dengan persentase 90, pada aspek membaca suku kata dengan persentase 61, dan pada aspek membaca kata dengan persentase 44. Sehingga diperoleh rata-rata ketiga aspek tersebut yaitu 65\%. Adapun data persentase tes kemampuan membaca permulaan dapat dilihat pada gambar diagram sebagai berikut:

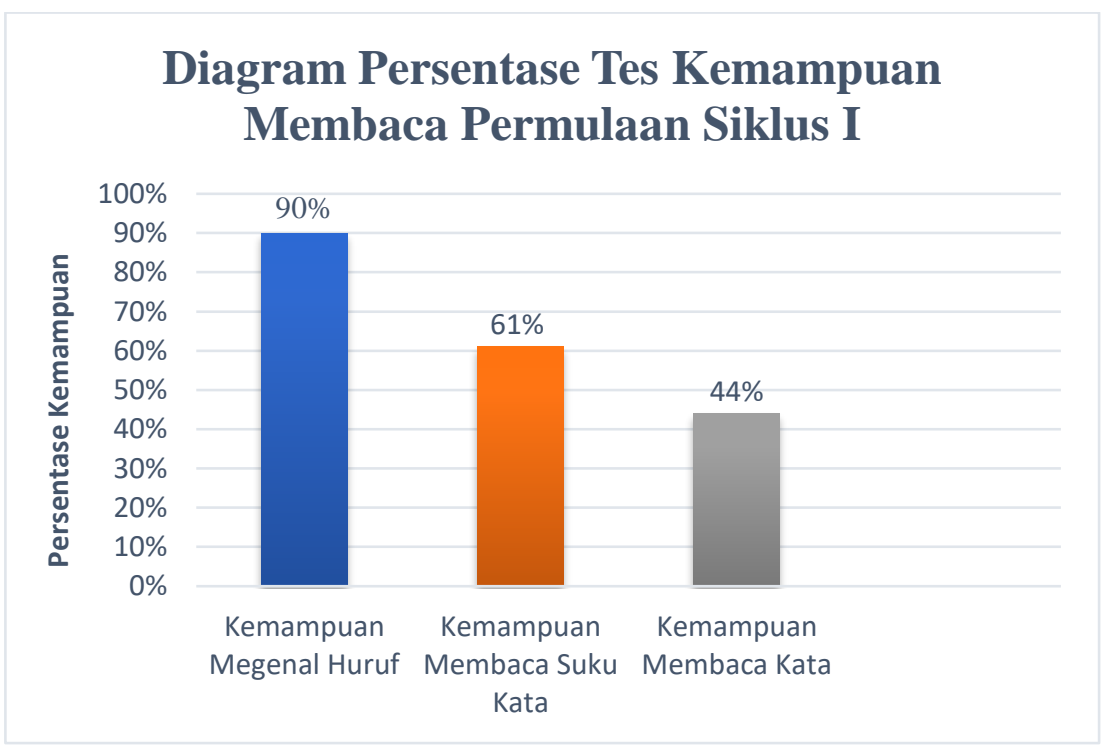

\section{Gambar 1. Diagram Persentase Tes Kemampuan Membaca Permulaan Siklus I}

Data hasil tes kemampuan membaca permulaan siswa pada siklus I menunjukkan bahwa persentase kemampuan mengenal huruf sebesar $90 \%$, kemampuan siswa dalam membaca suku kata sebesar $61 \%$, dan kemampuan siswa dalam membaca kata sebesar 44\%, rata-rata ketiga aspek tersebut yaitu 65\% dengan kategori cukup. Presentase tersebut masih belum mencapai indikator keberhasilan. Hal ini dikarenakan masih terdapat siswa yang masih kesulitan dan bingung dalam menyebutkan huruf secara acak, siswa yang kurang mampu membaca dengan baik sehingga 
menambahkan/menghilangkan beberapa huruf di awal kata maupun di akhir kata dan siswa yang mampu membaca kata namun tidak sesuai dengan teks.

Berdasarkan permasalahan tersebut maka peneliti memberikan solusi dari permasalahan yang terjadi pada siklus I, yaitu: guru membimbing masing-masing siswa dan mencontohkan bagaimana pelafalan huruf, guru menjelaskan kembali perbedaan huruf kapital dan huruf kecil pada aspek membilang huruf agar siswa mampu membedakan huruf yang sering salah dibaca.

Dari permsalahan dan solusi yang telah diberikan maka peneliti kemudian melanjutkan penelitian pada siklus berikutnya, yaitu pada siklus II untuk melakukan perbaikan sehingga diharapkan pada siklus II proses pembelajaran akan menjadi lebih optimal dan dapat meningkatkan aspek-aspek tersebut.

\section{Siklus II}

Hasil pengamatan Pada siklus II berbeda dengan hasil pengamatan pada siklus I dikarenakan adanya perkembangan dan peningkatan pada aspek kemampuan membaca permulaan. Nilai kemamapuan membaca siklus I berdasarkan aspek kemampuan membaca permulaan dideskripsikan pada tabel berikut ini:

Tabel 3 Nilai Kemampuan Membaca Siklus II Berdasarkan Aspek

\begin{tabular}{ccc}
\hline No. & Aspek & Persentase \\
\hline 1. & Mengenal Huruf & 93 \\
2. & Membaca Suku Kata & 69 \\
3. & Membaca Kata & 57 \\
\hline & Jumlah & 219 \\
\hline & Rata-rata & 73 \\
\hline Kategori & Baik \\
\hline
\end{tabular}

Berdasarkan tabel diatas menunjukkan bahwa nilai rata-rata siklus II pada aspek mengenal huruf dengan presentase 93, pada aspek membaca suku kata dengan persentase 69, pada aspek membaca kata dengan persentase 57. Sehingga diperoleh rata-rata pada ketiga aspek tersebut yaitu $73 \%$. Adapun data persentase tes kemampuan membaca permulaan dapat dilihat pada gambar diagram sebagai berikut:

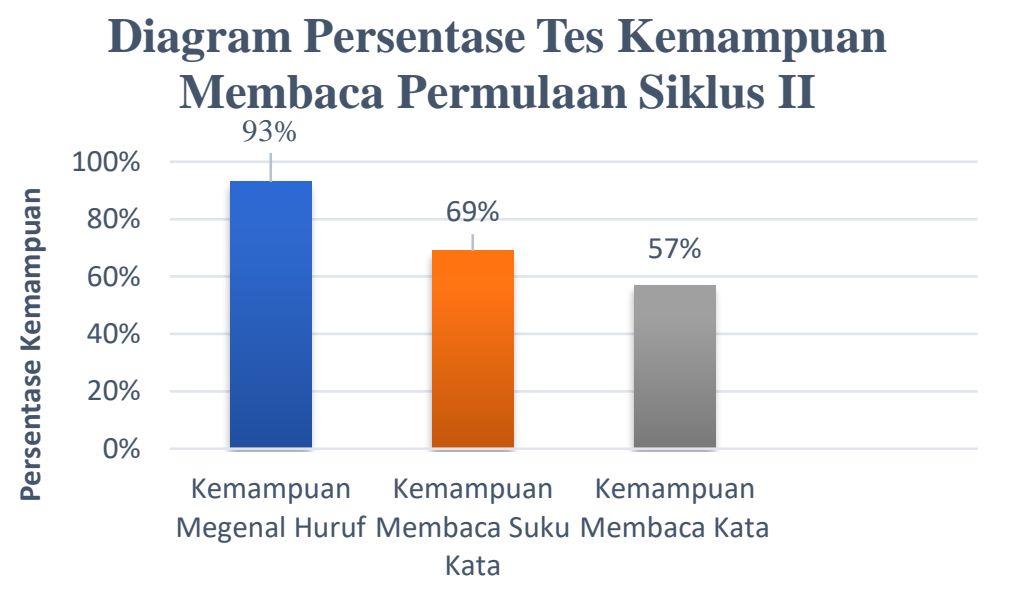

Gambar 2. Diagram Persentase Tes Kemampuan Membaca Permulaan Siklus II 
Data hasil tes kemampuan membaca permulaan siswa pada siklus I menunjukkan bahwa persentase kemampuan mengenal huruf sebesar $90 \%$, kemampuan siswa dalam membaca suku kata sebesar $61 \%$, dan kemampuan siswa dalam membaca kata sebesar $57 \%$, rata-rata ketiga aspek tersebut yaitu $73 \%$ dengan kategori baik.

Presentase tersebut telah mengalami peningkatan dari siklus I dan telah mencapai indikator keberhasilan pada penelitian ini. Hal tersebut dikarenakan siswa tertarik dan antusias dalam kegiatan membaca dengan menerapkan metode suku kata sehingga pembelajaran dapat berjalan dengan optimal, siswa telah mampu menyebutkan huruf secara acak, siswa sudah mampu membaca dengan baik tanpa menghilangkan/menambahkan huruf pada awal maupun akhir kata, dan siswa sudah mampu membaca kalimat yang panjang walaupun harus membaca ulang kata sebelumnya terlebih dahulu.

Dari hasil penelitian pada kedua aspek tersebut, aspek-aspek yang dinilai telah mengalami peningkatan dan mencapai indikator keberhasilan yang telah ditentukan, yaitu tingkat keberhasilan siswa mencapai 66-79\% dengan persentase kemampuan membaca permulaan minimal 66\%. Pada sikus II penelitian telah mengalami peningkatan. Berikut gambar diagram presentase peningkatan hasil tes kemampuan membaca permulaan siklus I dan siklus II.

\section{Persentase Hasil Tes Kemampuan Membaca Permulaan Siklus I dan} Siklus II

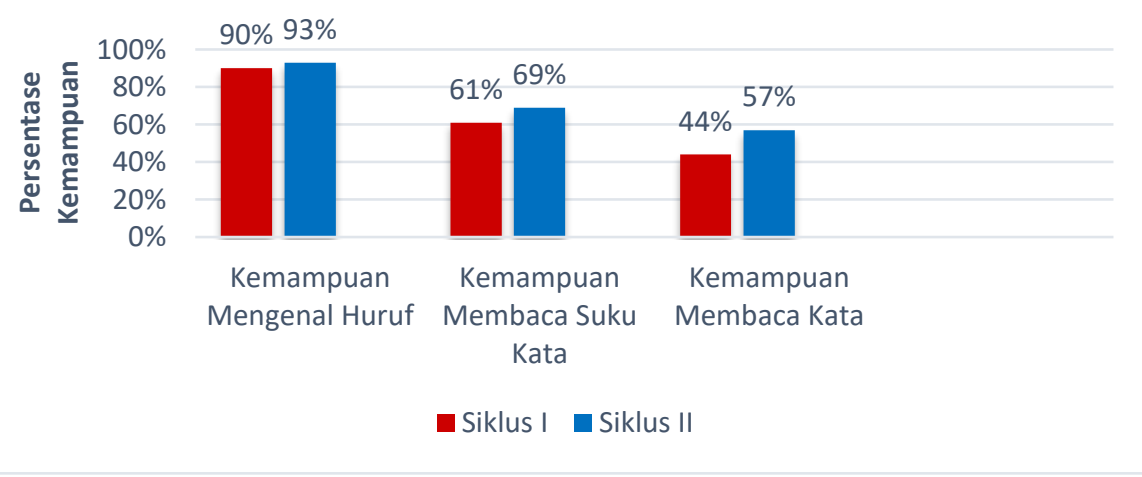

\section{Gambar 3. Digram Persentase Peningkatan Hasil Tes Kemampuan Membaca Permulaan Siklus I dan Siklus II}

Berdasarkan gambar diagram diatas peningkatan hasil tes kemampuan membaca permulaan telah mengalami peningkatan. Dapat dibuktikan pada siklus I hasil tes kemampuan membaca permulaan bahwa persentase kemampuan siswa dalam mengenal huruf sebesar $90 \%$, membaca kata sebesar $61 \%$, dan membaca kata sebesar $44 \%$, sehingga rata-rata kemampuan membaca yaitu $65 \%$ dengan kategori cukup dan selanjutnya mengalami peningkatan pada siklus II menunjukkan bahwa presentase kemampuan mengenal huruf sebesar 93\%, kemampuan siswa dalam membaca suku kata sebesar $69 \%$, dan kemampuan siswa membaca kata sebesar $57 \%$, sehingga ratarata kemampuan membaca $73 \%$ dengan kategori baik. Berdasarkan data di atas maka nilai tersebut telah mencapai indikator keberhasilan sehingga peneliti memutuskan untuk menghentikan penelitian pada sikus II.

Pernyataan tersebut dapat disimpulkan bahwa dengan penerapan metode suku kata (syllabic method) dapat meningkatkan kemampuan membaca permulaan siswa. 
Perkembangan dan pengenalan skema suku kata ini tidak mengharuskan anak-anak mempelajari alfabet sebelumnya (Díaz-Cárdenas et al., 2016). Suku kata lebih mudah diucapkan daripada banyak fonem (Díaz-Cárdenas et al., 2016). Kemampuan membaca suku kata dapat membantu memecahkan kode kata-kata dengan lebih lancar dan akurat, sehingga menghasilkan bacaan yang lancar dan pemahaman yang meningkat ((Güldenoğlu, 2016).

Menurut (Ukrainetz et al., 2011) metode ini dapat diterapkan untuk anak, dalam rangka memperbaiki dan meningkatkan kemampuan membaca permulaan. Hal ini ditambahkan oleh Nainggolan \& Rahdiani (2020) bahwa dengan metode syllabic siswa termotivasi untuk belajar dan rasa keingintahuan siswa besar dan semakin mampu membaca permulaan di kelas I. Peningkatan kemampuan membaca permulaan anak menggunakan metode suku kata (syllabic method) dilakukan secara bertahap dari yang mudah dan berlanjut pada tahap yang lebih sulit. Berdasarkan penjelasan diatas maka dapat ditegaskan keuntungan metode suku kata ini adalah untuk membantu anak kesulitan belajar yang cepat bosan, sehingga metode suku kata ini dapat digunakan untuk meningkatkan motivasi belajar membaca anak kesulitan belajar.

\section{SIMPULAN}

Berdasarkan hasil penelitian dan pembahasan yang telah dijabarkan maka dapat disimpulkan bahwa penelitian ini dilaksankaan dan berakhir sebelum masa pandemi covid-19 dengan menerapkan metode suku kata (syllabic method) dapat meningkatkan kemampuan membaca permulaan pada siswa kelas I-B di SDN 009 Tarakan. Hal tersebut dapat dilihat dari permasalahan yang dapat teratasi dan terjadi peningkatan pada setiap aspeknya yaitu peneliti menerapkan metode suku kata (syllabic method) pada setiap proses pembelajaran, peneliti juga meminta siswa 5 menit sebelum bel istirahat dan bel pulang sekolah berbunyi untuk meminta setiap anak membaca teks yang di berikan oleh guru.

Hal ini dapat dibuktikan pada kemampuan membaca permulaan yang terdiri dari 3 aspek, yaitu rata-rata pada aspek mengenal huruf siklus I yaitu 90 meningkat menjadi 93 pada siklus II. Pada aspek membaca suku kata siklus I yaitu 61 meningkat menjadi 69 pada siklus II. Pada aspek membaca kata siklus I yaitu 44 meningkat menjadi 57 pada siklus II. Sehingga pada siklus I diperoleh rata-rata persentase $65 \%$. Kemudian pada siklus II mengalami peningkatan, yaitu rata-rata persentase $73 \%$.

\section{DAFTAR PUSTAKA}

Alfiah, F., \& Umar, S. (2018). Pengembangan Media Big Book Terhadap Keterampilan Membaca Permulaan Dengan Metode Suku Kata. Joyful Learning Journal, 7(1), 19. https://doi.org/10.15294/jlj.v7i1.25087

Ayu, Q. R., \& Sudarsini. (2016). Metode Syllabic untuk Meningkatkan Keterampilan Membaca Permulaan Anak Autis. 2(1984), 21-23.

Basuki, B. (2019). Pengembangan Model Pembelajaran Membaca dengan Pelabelan Objek Sekitar (POS) untuk Murid taman Kanak-Kanak. DEEPUBLISH PUBLISHER.

Díaz-Cárdenas, A. F., Díaz-Furlong, H. A., Díaz-Furlong, A., \& Sankey-García, M. R. (2016). Syllabic Schemes and Knowledge of the Alphabet in Reading Acquisition: Onset or Nucleus Variation. International Education Studies, 9(11), 151. https://doi.org/10.5539/ies.v9n11p151

Ecalle, J., Kleinsz, N., \& Magnan, A. (2013). Computer-assisted learning in young poor readers: The effect of grapho-syllabic training on the development of word reading and reading comprehension. Computers in Human Behavior, 29(4), 1368-1376. https://doi.org/10.1016/j.chb.2013.01.041

Efendi, R., \& History, A. (2017). Penerapan metode silaba untuk meningkatkan keterampilan menulis permulaan pada mata pelajaran bahasa indonesia. II(2), 288299. 
Furoidah, R. R. F., \& Rohinah. (2019). Implementasi Metode Suku Kata ( Syllabic Method ) dalam Pembiasaan Membaca Awal Anak Usia Dini di Kelompok B1 TK IT Salsabila Al- Muthi' in Banguntapan. Pendidikan.

Güldenoğlu, B. (2016). The effects of syllable-awareness skills on the word-reading performances of students reading in a transparent orthography. International Electronic Journal of Elementary Education, 8(3), 425-442.

Halimah, A. (2014). Metode Pembelajaran Membaca Dan Menulis Permulaan di SD/MI. AULADUNA: Jurnal Pendidikan Dasar Islam, 1(2), 190-200. http://journal.uinalauddin.ac.id/index.php/auladuna/article/view/550/551

Havisa, S., Solehun, S., \& Putra, T. Y. (2021). Pengaruh Metode Suku Kata Mengunakan Media Kartu Huruf terhadap Kemampuan Membaca Permulaan Siswa Kelas I SD Muhammadiyah Majaran Kabupaten Sorong. Jurnal Papeda: Jurnal Publikasi Pendidikan Dasar, 3(1), 23-31. https://doi.org/10.36232/jurnalpendidikandasar.v3i1.765

Herdianingsih, M. F., Wahyuno, E., \& Pramono, P. (2019). Syllabic Method dalam Kemampuan Membaca Permulaan Siswa Tunagrahita. Jurnal ORTOPEDAGOGIA, 5(1), 39-43. https://doi.org/10.17977/um031v4i12018p039

Hidayah, W. N., \& Nawawi, A. (2017). Metode Suku Kata Untuk Pembelajaran Membaca Permulaan Peserta Didik Low Vision. Jassi Anakku, 18(2), 77-83.

Kumullah, R., Yulianto, A., \& Ida, I. (2019). Peningkatan Membaca Permulaan Melalui Media Flash Card pada Siswa Kelas Rendah Sekolah Dasar. Jurnal Pendidikan, 7(2), 36-42. https://doi.org/10.36232/pendidikan.v7i2.301

Muhyidin, A. (2017). PEMBELAJARAN MEMBACA DAN MENULIS PERMULAAN BAHASA INDONESIA DI KELAS AWAL. BAHTERA:Jurnal Pendidikan Bahasa Dan Sastra, 15.

Müller, B., Richter, T., \& Karageorgos, P. (2020). Syllable-based reading improvement: Effects on word reading and reading comprehension in Grade 2. Learning and Instruction, $\quad 66$ (January), https://doi.org/10.1016/j.learninstruc.2020.101304

Mustikawati, R. (2015). Upaya Peningkatan Keterampilan Membaca Permulaan Dengan Metode Suku Kata ( Syllabic Method ) Pada Siswa Kelas I SD Negeri Nayu Barat III Banjarsari Surakarta Tahun 2014/2015. Jurnal IImiah Mitra Swara Ganesha, 2(1), 41-56.

Nainggolan, M. F., \& Rahdiani, S. (2020). Upaya Meningkatkan Kemampuan Membaca Permulaan Menggunakan Syllabic Method. Jurnal TEKESNOS, 2(1), 49-56.

Nurhyati, Sugiyono, \& Uliyant, E. (2016). PENINGKATAN KEMAMPUAN MEMBACA NYARING SUKU KATA MENGGUNAKAN METODE DEMONSTRASI PEMBELAJARAN BAHASA INDONESIA SEKOLAH DASAR. Jurnal Pendidikan Dan Pembelajaran Khatulistiwa, 5.

Rusminiati, Halidjah, S., \& Tahmid Sabri. (2018). Peningkatan keterampilan membaca permulaan menggunakan media kubus suku kata siswa sekolah dasar. Jurnal Pendidikan Dan Pembelajaran Khatulistiwa, 7(3), 1-11.

Setiyoso, H., Studi, P., Guru, P., Dasar, S., Keguruan, F., Ilmu, D. A. N., \& Surakarta, U. M. (2020). MELALUI METODE SUKU KATA DENGAN MEDIA KARTU BERGAMBAR KELAS 1 SDN 01 BULUREJO TAHUN AJARAN.

Ukrainetz, T. A., Nuspl, J. J., Wilkerson, K., \& Beddes, S. R. (2011). The effects of syllable instruction on phonemic awareness in preschoolers. Early Childhood Research Quarterly, 26(1), 50-60. https://doi.org/10.1016/j.ecresq.2010.04.006

Yuliana. (2009). Analisis pelaksanaan bermain suku kata dalam mengembangkan kemampuan membaca permulaan pada anak usia dini. 1-12. 